\title{
Who Is Still Haunted by the Specter of Communism? Explaining Relative Output Contractions Under Transition
}

Julian Berengaut and Katrin Elborgh-Woytek 


\title{
IMF Working Paper
}

Middle East and Central Asia Department

\section{Who Is Still Haunted by the Specter of Communism? Explaining Relative Output Contractions Under Transition}

\author{
Prepared by Julian Berengaut and Katrin Elborgh-Woytek ${ }^{1}$
}

April 2005

\begin{abstract}
This Working Paper should not be reported as representing the views of the IMF. The views expressed in this Working Paper are those of the author(s) and do not necessarily represent those of the IMF or IMF policy. Working Papers describe research in progress by the author(s) and are published to elicit comments and to further debate.

The paper analyzes the initial output decline in transition economies by estimating a crosssection model stressing two major factors - conflicts and the legacies of the Soviet period. We link the Soviet legacies in place at the outset of the transition to the subsequent path for the development of market-related institutions. Institutional development (as proxied by measures of corruption) is used as an intermediate variable. An instrumental variable approach is followed to derive estimates that are not biased by the possible endogeneity of corruption with respect to output developments. Assuming that the extent of Soviet legacies was positively correlated with the length of the communist rule allows us to use the years under the Soviet regime as an instrument.
\end{abstract}

JEL Classification Numbers: O57, P20, E20, E65

Keywords: Commonwealth of Independent States; CIS

Author(s) E-Mail Address: jberengaut@imf.org; kelborghwoytek@imf.org

\footnotetext{
${ }^{1}$ We wish to thank Mohsin S. Khan and other participants in an IMF Middle East and Central Asia Department (MCD) seminar for valuable comments. Helpful comments were also provided by Andrzej Raczko. Thanks are due to Mandana Dehghanian for excellent research assistance, and Maria Llames for outstanding project support.
} 


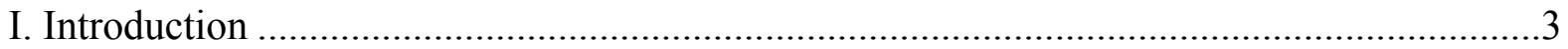

II. Relative Output Performance in the Transition Process ................................................4

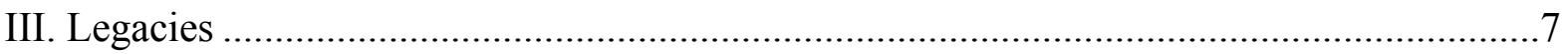

A. Common Soviet Legacies .......................................................................

B. Impact of Legacies on Institutions and the Memory of Institutions ........................ 7

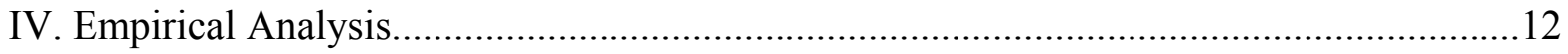

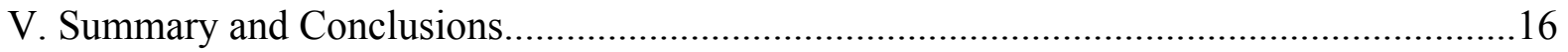

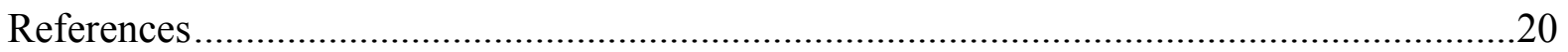

\section{Text Tables}

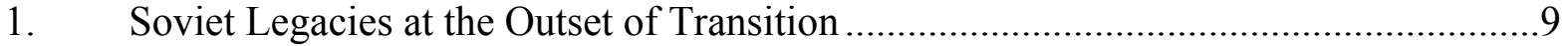

2. Duration of Soviet Rule in Transition Economies ..................................................... 14

3. Instrumental Variable Equation ....................................................................... 15

4. Instrumental Variable Estimates for the Model .....................................................15

Figures

1. Output Decline in Four Groups of Transition Economies, 1989-2002 ......................5

2. Output Recovery in Four Groups of Transition Economies .....................................6

3. Evolution of Real GDP for China and Other Transition Economies since the Onset of Transition .............................................................................. 7

4. Channels for Impact of Soviet Legacies on Post-Soviet Output Decline ....................8

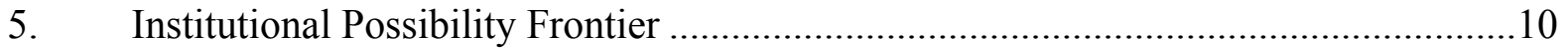

6. Institutional Possibility Frontier for Visegrad and CIS Countries............................11

7. Schematic Classification of Transition Economies ..............................................16

Appendix Tables

1. Real GDP Index for Transition Economies, 1989-2003 ....................... 18

2. Conflicts During the Early Transition Phase.................................. 19 


\section{INTRODUCTION}

In the countries of Central and Eastern Europe and the former Soviet Union, the early transition phase was marked by a substantial fall in output (see Appendix Table 1). This decline has been the subject of extensive research ${ }^{2}$ and has been attributed to a multitude of factors. The first wave of research on this topic stressed inter alia: (a) the sudden breakdown of central planning as a key mechanism for the allocation of resources and the coordination of economic activities; (b) disruptions of production links and energy supplies as a result of the establishment of national borders; (c) the breakdown of the payments system; (d) the dissolution of the Comecon as a coordinator for external transactions; (e) a credit crunch caused by efforts to establish macroeconomic stability; (f) the introduction of new currencies; and $(\mathrm{g})$ misaligned exchange rates leading to overly strong competition by imports from developed market economies.

The second wave of research focused on additional factors such as difficulties in establishing market institutions, in line with the general recognition of the importance of institutions in explaining relative growth outcomes. ${ }^{3}$ However, the inclusion of indices of institutional quality among explanatory factors raises difficult questions about the direction of causality, given the possible endogeneity of right-hand side variables.

This paper aims to contribute to the literature on the subject of output decline under transition by elaborating and estimating a parsimonious cross-section model of output decline that stresses two major factors - conflicts and institutional quality (proxied by corruption), which in turn are determined by Soviet-era legacies. An instrumental variable (IV) approach is followed to derive estimates that are not biased by the possible endogeneity of institutional quality with respect to relative output developments. The crucial link is between the Soviet legacies that were in place when the transition was launched and the subsequent path for the development of market-related institutions, under the assumption that the extent of Soviet legacies was positively correlated with the length of the communist rule. We allow for the possibility that the relationship between the length of the Soviet rule and the "endorsement" of Soviet legacies could be nonlinear, especially in terms of possible generational effects in relation to the knowledge of market institutions. Recognizing the link between legacies and

\footnotetext{
${ }^{2}$ Berengaut and others (1998); Berengaut and others (2002); Berg and others (1998); De Broeck and Koen (2000); De Melo and others (2001); Elborgh-Woytek (2003); Fischer and Sahay (2000); Havrylyshyn and others (2000); Radulescu and Barlow (2002).

${ }^{3}$ See World Economic Outlook, April (2003), pp. 95-128; Havrylyshyn and van Rooden (2003); Falcetti and others (2002); Fischer and others (1996).
} 
institutions allows us to use the length of the period of communism as an instrument for estimating the effects of institutional development on the relative output contractions. ${ }^{4}$ We limit our attention to the period during which output declined and do not address the relationship between the depth and length of the contractions and the patterns of subsequent recovery, such as the findings of a positive correlation between the depth of the contraction and the speed of the subsequent recovery. ${ }^{5}$ Although the recovery of output has been under way for some time in most of the transition economies, most of them have not yet fully recovered to pre-transition levels. In this sense, the specter of communism is still haunting these economies.

The remainder of the paper proceeds as follows. Section II presents the basic facts about output contractions in transition economies. Section III surveys the most common Soviet legacies that the transition countries inherited at the outset of their transition, stressing the peculiar combination of totalitarian politics, which hindered the development of civil society, and administrative management of the economy, which resulted in pervasive distortions and the lack of market institutions. It goes on to analyze the impact of these legacies on the subsequent institutional developments using the model of New Institutional Economics as formulated by Djankov and others (2003). Section IV, after discussing measures of institutional quality, presents the model and the estimates of its parameters. Section V summarizes and offers conclusions.

\section{Relative Output Performance in the Transition Process}

Our sample of 25 transition countries consists of four different groups of economies: the Visegrad countries (the Czech Republic, Hungary, Poland, and the Slovak Republic); the countries of the Balkan region (Albania, Bulgaria, Croatia, the former Yugoslav Republic of Macedonia, Romania, and Slovenia); ${ }^{6}$ the Baltic countries (Estonia, Latvia, and Lithuania); and the 12 Commonwealth of Independent States (CIS) countries (Armenia, Azerbaijan, Belarus, Georgia, Kazakhstan, the Kyrgyz Republic, Moldova, Russia, Tajikistan, Turkmenistan, Ukraine, and Uzbekistan). As demonstrated in Figure 1, the severity of the output decline varied considerably among these four groups of countries. ${ }^{7}$

\footnotetext{
${ }^{4}$ In spirit, our approach is similar to that of Acemoglu and others (2001), who use differences in settlers' mortality in different geographical locations as an instrument for the subsequent institutional development in those locations.

${ }^{5}$ For evidence of this phenomenon at both micro and macro levels see Berengaut and others (2002)and the EBRD Transition Report (2004).

${ }^{6}$ Data available for Bosnia and Serbia and Montenegro are insufficient for the purposes of this paper.

${ }^{7}$ As we aim to analyze relative output contractions, we address neither Åslund's contention that the decline in broad measures of output, such as GDP, was mainly statistical (Åslund, 2001) nor the well-known fact that various measures of consumption did not decline by comparable amounts.
} 
Figure 1. Output Decline in Four Groups of Transition Economies, 1989-2002

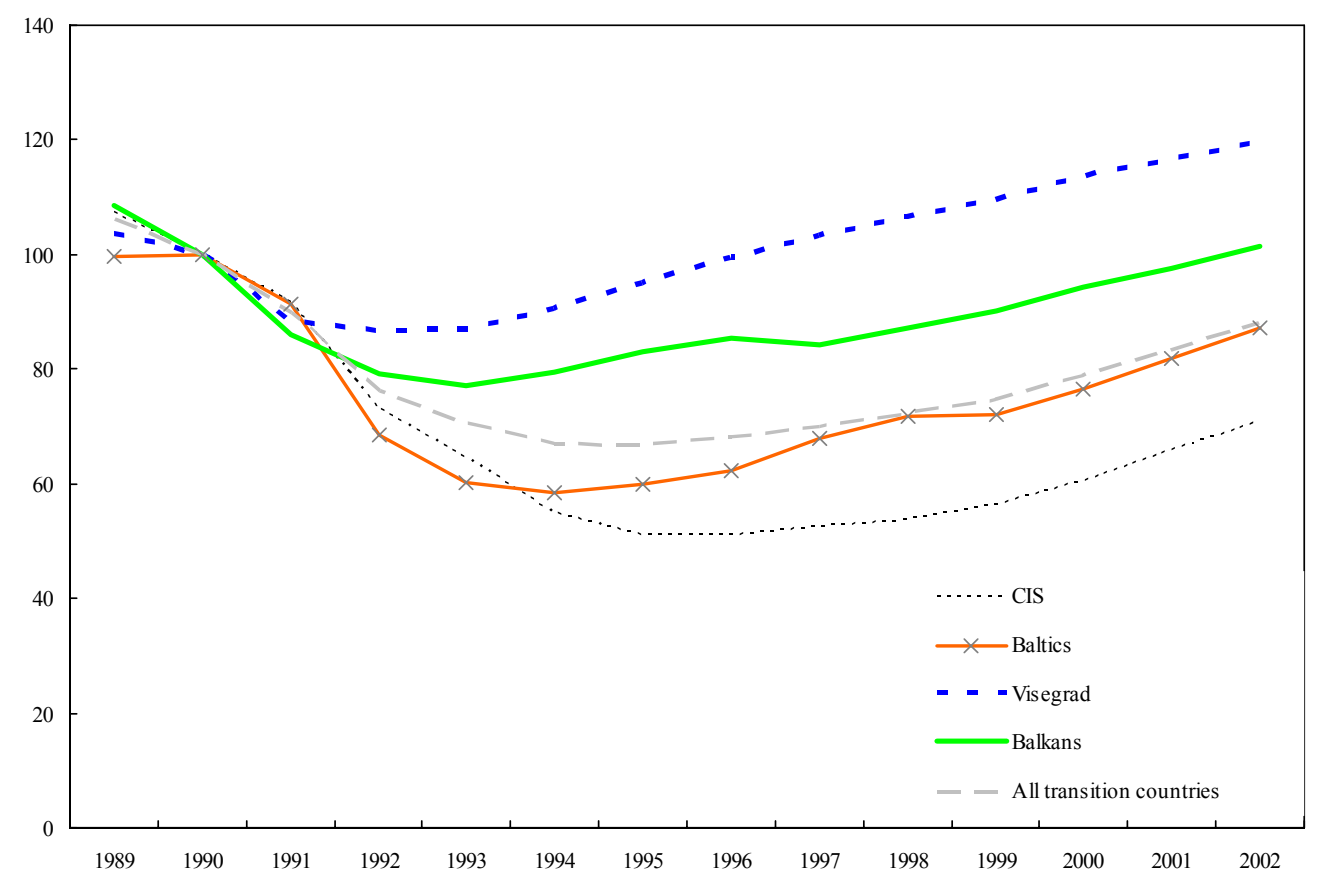

Source: Country authorities.

Although output declined in all of these economies, there were significant differences in the transition paths: while the fall in output amounted to only 16 percent in the Czech Republic and Poland, it reached more than 60 percent in Georgia, Moldova, and Ukraine. Most economies recorded their trough (T) within the first five years of the transition process; however, Moldova and Ukraine reached their lowest point in real output only toward the end of the transition decade, in 1999. As can be seen in Figure 2, economic growth in the four groups of countries following the trough demonstrates a rather high degree of similarity. Accordingly, differences in the overall output performance are mainly explained by the intensity of the initial fall in output. 
Figure 2. Output Recovery in Four Groups of Transition Economies

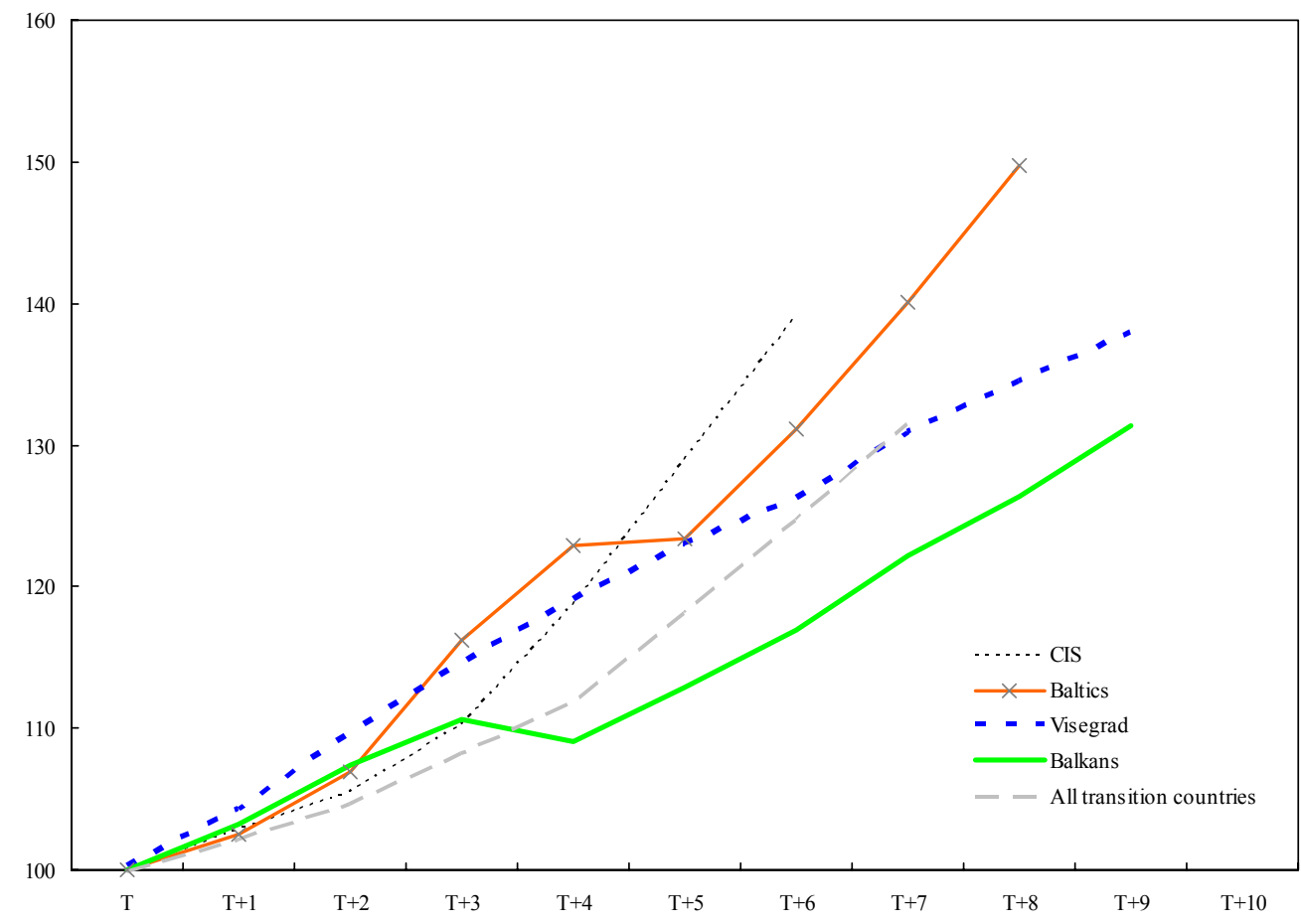

Source: Country authorities.

The Chinese transition process stands in sharp contrast to the developments in the transition economies of Central and Eastern Europe and the former Soviet Union, since China's output did not decline in the course of transition (Figure 3). Indeed, if output developments in other transition economies are shown on the same scale as those for China with its rapid growth, their output decline appears rather shallow. There have been numerous attempts to explain this Chinese exceptionalism, ${ }^{8}$ with the majority of explanations converging on the combined effects of initial conditions, especially the low share of industry relative to agriculture, and broad macroeconomic stability.

\footnotetext{
${ }^{8}$ See Lardy (1998); Lin (1996); and Prasad (2004).
} 
Figure 3. Evolution of Real GDP for China and Other Transition Economies since the Onset of Transition

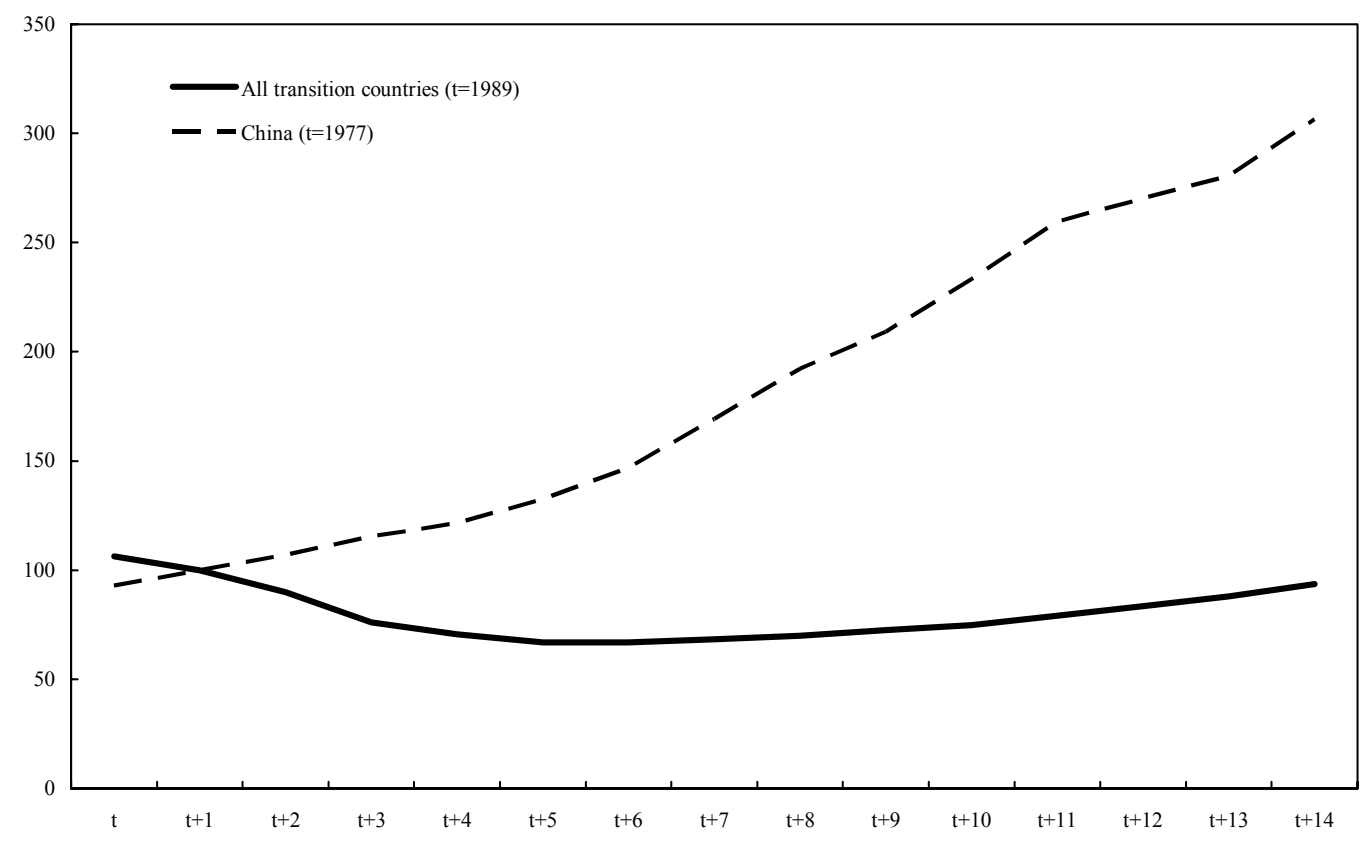

Source: Country authorities.

\section{LEGACIES}

\section{A. Common Soviet Legacies}

In our analysis, we employ the two key assumptions that (a) Soviet policies were detrimental to developing market institutions, as set out above; and that (b) different transition countries started the transition process with different endowments of Soviet legacies. At the outset of transition, specific legacies were either weak (for example, in the Central and Eastern European (CEE) countries) or absent (as in the CIS countries). The difference between "weak" and "absent" is essential, and it is this difference that is exploited in the paper. Table 1 summarizes the legacies, which in our view have had the greatest influence on the performance of former socialist economies during the transition process. ${ }^{9}$

\section{B. Impact of Legacies on Institutions and the Memory of Institutions}

We postulate that the impact of Soviet legacies on post-Soviet output decline comprises both linear and nonlinear effects (Figure 4). The communist legacy can be expected to have a linear negative effect on output due to the factors listed in Table 1, which can be summarized

\footnotetext{
${ }^{9}$ Some of these features are prevalent even in nontransition developing countries. The list is not exhaustive.
} 
as "absence of market institutions." In addition, the Soviet system has, due to its relatively long duration, eradicated specific human capital comprising the memory of functioning markets, resulting in the absence of knowledge of market institutions due to nonlinear "generational" effects.

Figure 4. Channels for Impact of Soviet Legacies on Post-Soviet Output Decline

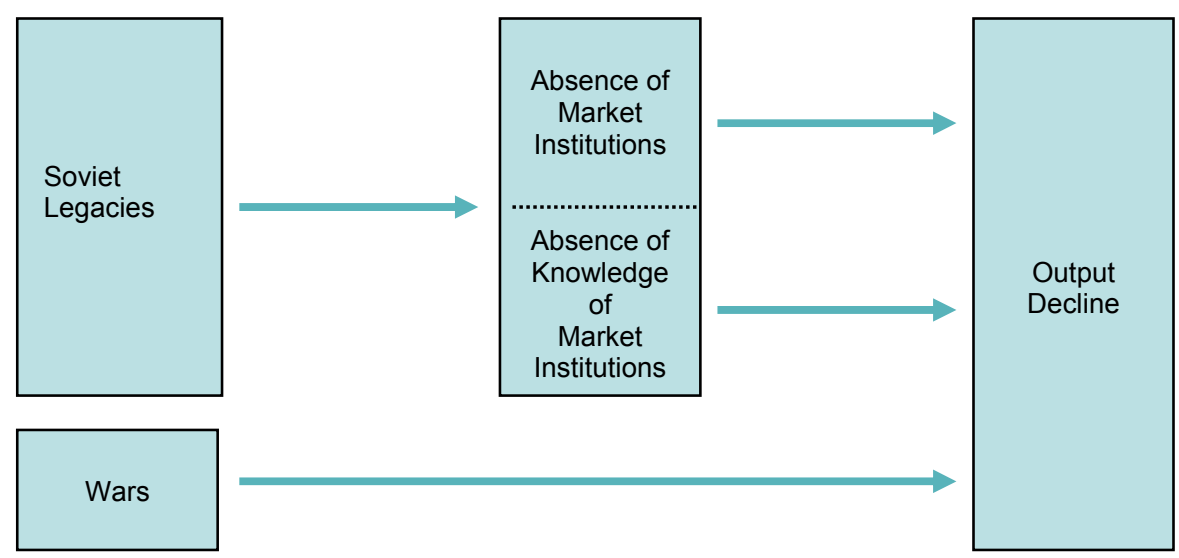

The effects of Soviet legacies and the subsequent development of institutions can be examined in a framework, ${ }^{10}$ according to which any society faces the two opposite dangers of disorder and dictatorship. On the one hand, disorder equals the risk of private expropriation - in the extreme, by murder or other forms of violence, but also through monopoly pricing. Dictatorship, on the other hand, entails the risk of expropriation by the state and its agents - again, with murder at the extreme. Corruption can be the result of either disorder and dictatorship, or both. Institutions serve as a means to control these two risks. Figure 5 shows the Institutional Possibility Frontier (IPF) for a given society or a sector, reflecting the institutional possibilities, the shape and location of which vary across societies. In this framework, the $\mathrm{x}$-axis depicts the social losses from dictatorship, while the y-axis shows the social losses from disorder, both measured against a perfect property rights benchmark. The 45-degree line depicts constant total social costs of dictatorship and disorder, and the efficient institutional choice for a society or a sector is the point of tangency with the IPF. Djankov and others (2003) refer to the location of the IPF as "civic capital," assuming that societies with an IPF closer to the origin would demonstrate better capacities to achieve cooperation among their members.

In the context of transition, the dissolution of the socialist economic system initially resulted in a high degree of economic disorganization, which continued to some extent even when the market began to work. Significant differences exist between the groups of countries we aim

\footnotetext{
${ }^{10}$ Djankov and others (2003).
} 
Table 1. Soviet Legacies at the Outset of Transition ${ }^{1}$

\begin{tabular}{|c|c|}
\hline Legacy & Effect \\
\hline $\begin{array}{l}\text { Weak/absent markets (especially for capital, foreign } \\
\text { exchange, energy, housing, and labor) }\end{array}$ & $\begin{array}{l}\text { - Sharp deviations of domestic prices from world } \\
\text { market prices } \\
\text { - Capital- and energy-intensive production structure } \\
\text { with a bias against consumption goods } \\
\text { - Low labor mobility } \\
\text { - Widespread quasi-fiscal activities } \\
\text { - Noneconomic locational decisions resulting in large- } \\
\text { scale, horizontally and vertically integrated companies, } \\
\text { one-company towns, and high transportation costs } \\
\text { - Absence of well-defined property rights } \\
\text { - Very limited trade with countries outside } \\
\text { COMECON }\end{array}$ \\
\hline Weak/absent private sector activity & $\begin{array}{l}\text { - Hostile business environment } \\
\text { - Difficulties in privatization }\end{array}$ \\
\hline Weak/absent tax systems & $\begin{array}{l}\text { - Institutional weaknesses in tax collection agencies } \\
\text { - Widespread tax exemptions and corruption }\end{array}$ \\
\hline Weak/absent commercial banking sector & $\begin{array}{l}\text { - Low quality of banks and loans } \\
\text { - Fragmentation of banking sector with weak new } \\
\text { institutions ("pocket banks") }\end{array}$ \\
\hline Weak/absent legal systems & $\begin{array}{l}\text { - Political influence on court decisions } \\
\text { - Absence of clearly defined property rights } \\
\text { - Corruption/political approach to legal norms } \\
\text { - "Telephone" law }\end{array}$ \\
\hline $\begin{array}{l}\text { Weak/absent efficiency and integrity of public } \\
\text { administration }\end{array}$ & $\begin{array}{l}\text { - Multiple layers of government with separation of } \\
\text { authority and accountability } \\
\text { - Overstaffing in government services and } \\
\text { administration }\end{array}$ \\
\hline Weak/absent official accountability & $\begin{array}{l}\text { - Totalitarian political systems with lack of constraints } \\
\text { on official discretion } \\
\text { - Inadequate statistics, resulting in difficulties in } \\
\text { obtaining reliable economic data }\end{array}$ \\
\hline Weak/absent civil societies & $\begin{array}{l}\text { - Lack of transparency } \\
\text { - Absence of counterweight to official decisions } \\
\text { - Underdeveloped political institutions } \\
\text { - Lack of independent press }\end{array}$ \\
\hline Weak/absent environmental protection & $\begin{array}{l}\text { - Health and clean-up costs } \\
\text { - Lower productivity, especially in agriculture }\end{array}$ \\
\hline
\end{tabular}

${ }^{1}$ See, among many other sources, Bradshaw (1996); Carley (1995); Feshbach (1995); Henley and Assaf (1996); Hill and Gaddy (2003); Kangas (1995); Kubicek (2002); Makushin (1993); Mnatsakanian (1992); Peterson (1993); Rutkowski (1996); Tanzi (1996); and Wallich (1996). 
to analyze. For instance, among the CIS countries, the decline in dictatorship was more significant in Russia than in Belarus and Uzbekistan, because Russia overshot its institutional change toward excessive disorder in the early transition phase. ${ }^{11}$ In nonreforming states, such as Belarus and Uzbekistan, a large part of the controlling institutions, which had been operating under the Soviet regime, remained intact, implying only a marginal move upward on the IPF, and, ultimately, a much smaller decline in output than in most other CIS countries. Eastern Europe's more attractive IPF is explained by (a) a shorter period of communist rule; (b) the existence of more independent organizations (e.g., the Catholic church in Poland); and (c) a higher degree of integration with other European countries.

Figure 5. Institutional Possibility Frontier

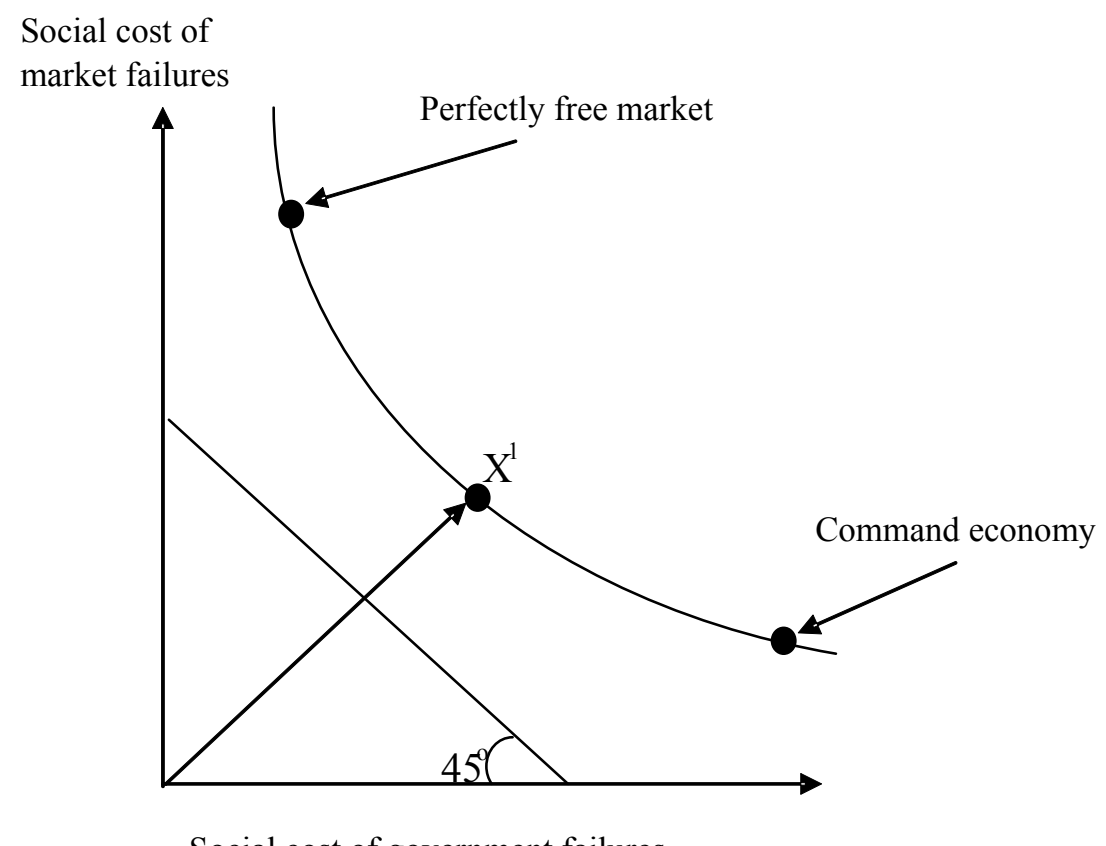

Social cost of government failures

Source: Based on Djankov and others (2003).

Applied to the specific case of transition economies, the framework suggests the results demonstrated in Figure 6. Compared with the CIS economies, the Visegrad countries incurred lower costs of both government and market failures. In the early transition phase, between 1992 and 1996, these countries moved from a situation characterized by a rather high degree of government failure to a point on their utility curve, which minimizes government and market failure (from A to B). In contrast, at the outset, the CIS countries

${ }^{11}$ Djankov and others find that "Russia's IFP is probably less attractive than that of the East European countries and, at the same time, its shift along the IPF was probably greater" (Djankov and others, 2003, p. 26). 
demonstrated a significantly higher degree of government failure and a somewhat higher degree of market failure than the Visegrad countries. That is, their IPF was significantly farther away from the origin than that of Visegrad countries. Moreover, in the course of the transition process, while reducing the costs of government failure, these economies overshot, to incur substantially higher costs of market failures (from $C$ to D). The subsequent move at a later stage (to point E) ensured the optimum choice between the social costs of government and market failure, remaining, however, substantially above the costs incurred by the Visegrad countries. That is, their IPF was significantly farther away from the origin than that of the Visegrad countries.

Figure 6. Institutional Possibility Frontier for Visegrad and CIS Countries

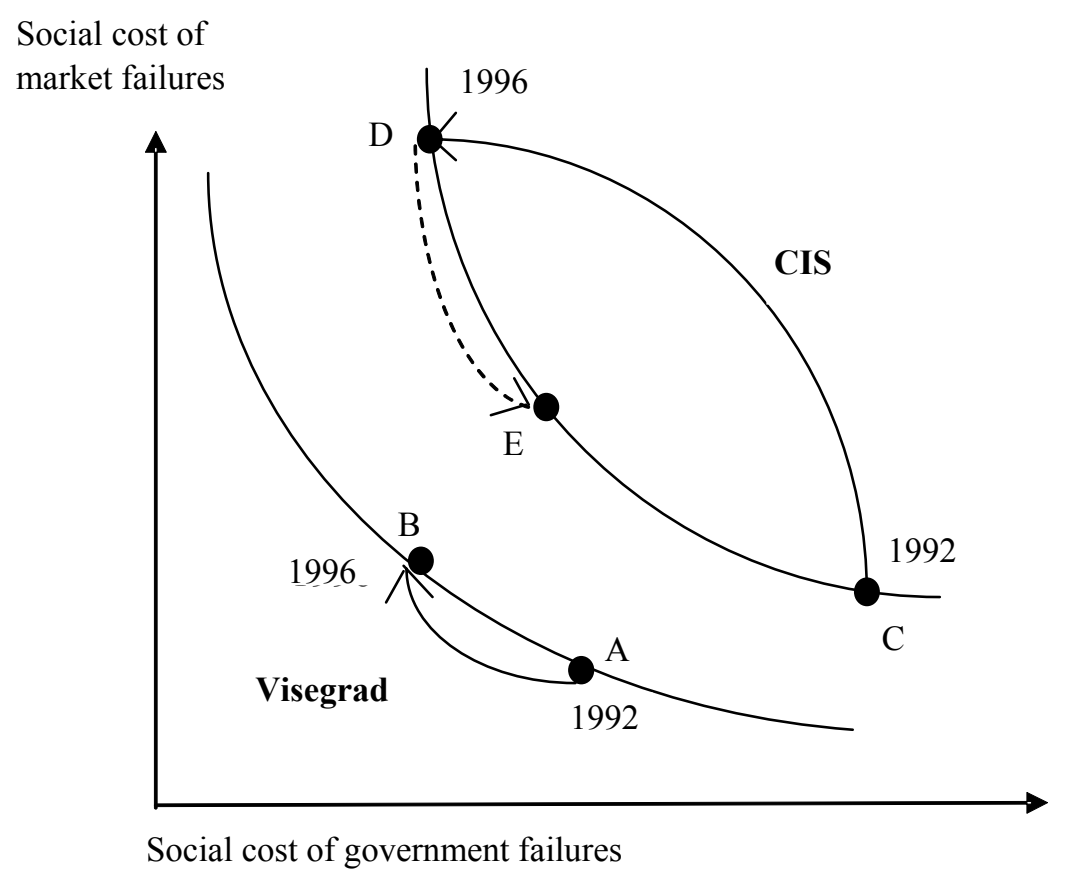

The introduction of personal income tax (PIT) can serve as an example for the contrast between the CEE countries and the countries of the former Soviet Union. In most of the CEE countries, the PIT existed, although its function was not to collect revenue but rather to control the size of the private sector. To change the focus of the existing PIT from control to revenue collection was relatively easy, equivalent to a move from A to B. However, in the Soviet Union, the PIT did not exist and had to be established from scratch, equivalent to a move from $\mathrm{C}$ to $\mathrm{D}$. Accordingly, the establishment of a PIT framework in the FSU was subject to the Hobbesian problem for establishing institutions: "The notion that simply instituting an appropriate legal regime will establish a set of property rights that can undergird a modern economic system is deeply implausible, because most property rights can only be marginally enforced by the legal system. The core of the institution of ownership is a matter of unquestioned and largely unconscious social and economical practices that must be rooted in nonlegal developments. This is the old Hobbesian problem: when most people obey 
the law, the government can enforce it effectively and relatively cheaply against the few individuals who break it. But when obedience breaks down on a large enough scale, no authority is strong enough to police everyone" (Rapaczynski, 1996).

The description of Soviet legacies outlined above suggests two broad hypotheses, which will be examined empirically below: (a) in general, these legacies have had adverse effects on growth; and (b) the effects on growth depend on how deeply entrenched the legacies were at the outset of the transition.

\section{EMPIRICAL ANALYSIS}

As there already exists a substantial literature on the possible reasons for output decline, this paper focuses on explaining relative differences in output contractions among the four groups of countries. We pursue a parsimonious approach and aim to explain these differences with a very limited set of explanatory variables: conflicts within countries or with other countries; the quality of post-Soviet institutions; and the duration of Soviet rule. Our choice is not to include policy variables in the model since institutions constitute a more fundamental feature of a given economy (IMF, 2003). We have attempted to take account of geographical variables (various measures of distance to Western Europe), but the coefficients were not significant. ${ }^{12}$ The model is specified as follows: ${ }^{13}$

$$
\begin{aligned}
& \mathrm{Y}_{\mathrm{i}}=\beta_{\mathrm{o}}+\stackrel{(+)}{\beta} \mathrm{C}_{\mathrm{i}}+\stackrel{(-)}{\beta} \mathrm{S}_{\mathrm{i}}^{2}+\stackrel{(-)}{\beta} \mathrm{I}_{\mathrm{iIV}}+\varepsilon_{\mathrm{i}} \\
& \mathrm{I}_{\mathrm{jIV}}=\beta_{4}+\stackrel{(-)}{\beta} \mathrm{S}_{\mathrm{j}}+\varepsilon_{\mathrm{j}} \\
& \text { with } \\
& \mathrm{Y}=\text { output loss } \\
& \mathrm{C}=\text { conflict } \\
& \mathrm{I}_{\mathrm{IV}}=\text { instrumental variable for institutions (corruption index for 1996) } \\
& \mathrm{S}=\text { years of Soviet rule } \\
& \varepsilon=\text { the error term } \\
& \mathrm{i}, \mathrm{j}=1, \ldots, 25 \text { (transition economies) }
\end{aligned}
$$

\footnotetext{
${ }^{12}$ Other studies have tried to assess the importance of initial conditions on subsequent output developments. The EBRD Transition Reports for 2002 and 2004 have presented estimates of the relationship between an index of initial conditions and subsequent growth in transition economies. The index includes the number of years a country endured central planning, a statistic closely related to the instrumental variable we use. The EBRD index is derived as a principal component of a broad set of variables, including GDP per capita, pre-transition growth, a dummy for natural resources, the share of urban population, distance to Brussels, shares of sectoral employment relative to market economy benchmarks, measures of repressed inflation, black market premia, a dummy for state "capacity," etc. The heterogeneous nature of the variables used to construct this index and the inclusion of the index alongside other variables render the estimated coefficients difficult to interpret.

${ }^{13}$ Signs in parentheses show the expected coefficient signs.
} 
We define output loss as the decline in output from the last pre-transition year (set at 100) to the trough, using a real GDP index based on the last pre-transition year, on the assumption that pre-transition levels of output are comparable. For conflicts we employ a dummy variable, which is equal to 1 for countries that experienced armed conflict during their early transition phase, and is 0 for all others, based on data from the Swedish International Peace Research Institute (SIPRI). ${ }^{14}$

Our framework of institutional quality is based on the broad index of institutional development compiled by Kaufmann and others (2003), which aggregates a large number of individual variables for perceptions of governance along six basic dimensions. The authors estimate the quality of six dimensions of governance for 199 countries and territories for 1996, 1998, 2000, and 2002, utilizing 250 individual measures from 25 different sources, compiled by 18 different organizations. ${ }^{15}$ As we are most interested in the impact of institutional quality on the early transition phase, we use data for 1996. The index relies on subjective perceptions-based measures of governance because objective data are very difficult to establish; both polls of experts and broader surveys are used. The indicators range from -2.5 to 2.5. Although variance remains substantial, changes over time in the perceptions of a certain country tend to be small. The precision of aggregate indicators has been strengthened by including a large number of individual surveys. We have selected the indicator for corruption on the grounds that it is the one affecting the performance of economic agents most directly. ${ }^{16}$

However, since the use of the quality of institutions as an explanatory variable for output loss could result in endogeneity, we introduce as an instrumental variable the intensity of Soviet rule, proxied by the duration of the Soviet regime, in the respective countries (Table 2).

\footnotetext{
${ }^{14}$ Appendix Table 2 lists the conflicts in transition countries during the early transition phase. The ongoing Chechnya conflict has been excluded because its impact on the Russian economy has likely been more limited than the economic impact of conflicts in other countries.

15 These include international organizations, rating agencies, think tanks, and nongovernmental organizations, such as the Economist Intelligence Unit, the World Bank's Country Policy and Institutional Assessment, Gallup International, World Economic Forum's Global Competitiveness Report, Millennium Challenge Account, and the World Bank's business environment surveys.

16 The other indicators are (a) voice and accountability; (b) political stability and absence of violence; (c) government effectiveness; (d) regulatory quality; and (e) rule of law.
} 
Table 2. Duration of Soviet Rule in Transition Economies

\begin{tabular}{llcl}
\hline Country or Group & & & \\
of Countries & Duration of Soviet Rule & $\begin{array}{l}\text { Number } \\
\text { of Years }\end{array}$ & Comments \\
& & 64 & 1928: First Five-Year Plan \\
CIS, except Moldova & $1928-91$ & 50 & \\
Moldova & $1940-41$ and 1944-91 & 49 & \\
Baltic countries & $1940-41$ and 1944-90 & 43 & 1947: Establishment of Cominform 1/ \\
Visegrad and Balkan countries & $1947-89$ & & \\
\hline
\end{tabular}

1/ It will be recalled that the establishment of Cominform in 1947 at the Szklarska Poręba Conference marked the beginning of enforcing uniform Sovietization across Eastern Europe.

While most of the CIS countries became Soviet republics either shortly after the Russian revolution or in the early 1920 s, Soviet rule in the economic sense began only in 1928 with the first five-year plan. Moldova constitutes an exception because it was a part of Romania (Bessarabia) until 1940, when it was invaded by Soviet troops; following German and Romanian occupation during 1941-44, the country was reoccupied by Soviet forces in 1944. The Baltic countries came under the Soviet regime at the same time as Moldova, but became independent one year earlier, in 1990. The Visegrad and Balkan countries endured Soviet rule for a shorter period of time than the other transition economies - between 1947, when Communist regimes were established in most of them, and 1989, when the Berlin Wall fell. It can be argued that this classification of countries constitutes a simplification because the impact on institutions of one year of Soviet rule in Ukraine in the 1930s differed considerably from one year of Soviet rule in Hungary in the 1980s. More generally, Soviet rule in the Balkans and Visegrad countries, at least since the 1960s, was significantly less severe than the regime in most republics of the Soviet Union. However, as the severity of Soviet rule is difficult to quantify, we use the duration of the regime as a proxy for the institutional impact.

We recognize that the mechanistic measurement of the impact of the Soviet period on the societies and economies by the number of years is subject to limitations. In principle, one could try to account for this impact by direct measures of the damage inflicted-for instance, the numbers of political prisoners or forced exiles. While estimates of these magnitudes exist (Courtois, 1999), in view of the nature of the data, their use would not be without important limitations either.

We also take into account the cumulative effect of Soviet rule by introducing nonlinearities with regard to the duration of the Soviet regime. Soviet rule that extends significantly beyond one generation (e.g., 30-40 years) could be expected to have increasingly adverse effects. This is because the memory of market institutions can be expected to die out once the generation with a memory of how market institutions worked (or indeed what market institutions were) has died out. 
Table 3. Instrumental Variable Equation

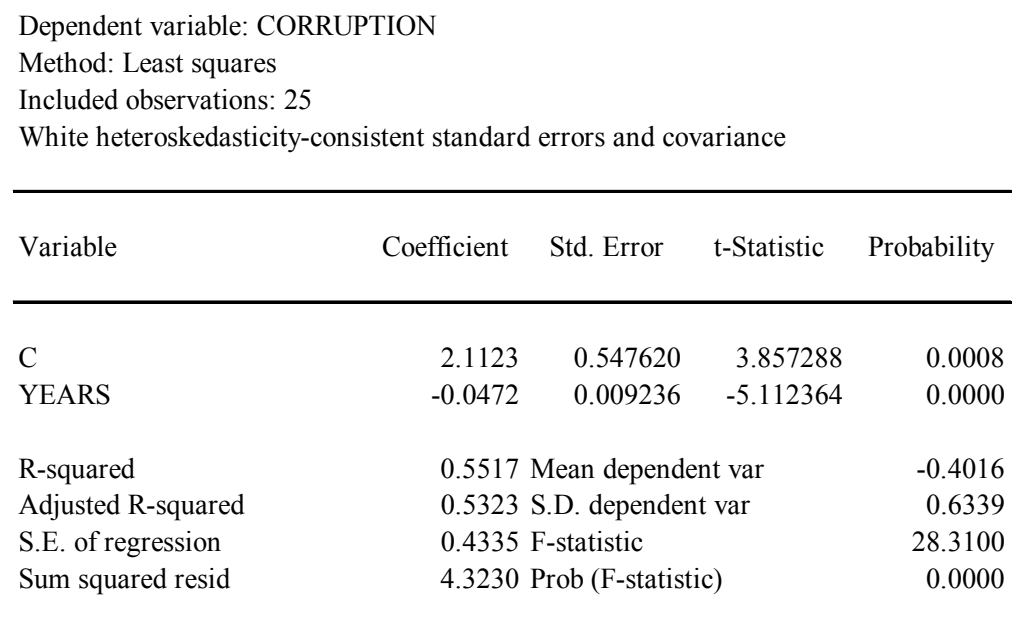

As can be seen in Table 3, the regression results show a good fit, with a value for R-squared of 0.55 , and a highly significant coefficient for years of Soviet rule. The estimates for the equation using the instrumental variable are summarized in Table 4. Regression results demonstrate substantial explanatory power, as indicated by the R-squared of 0.62 , which is quite high for cross-section data. All coefficients show the expected signs ${ }^{17}$ and are highly significant.

Table 4. Instrumental Variable Estimates for the Model

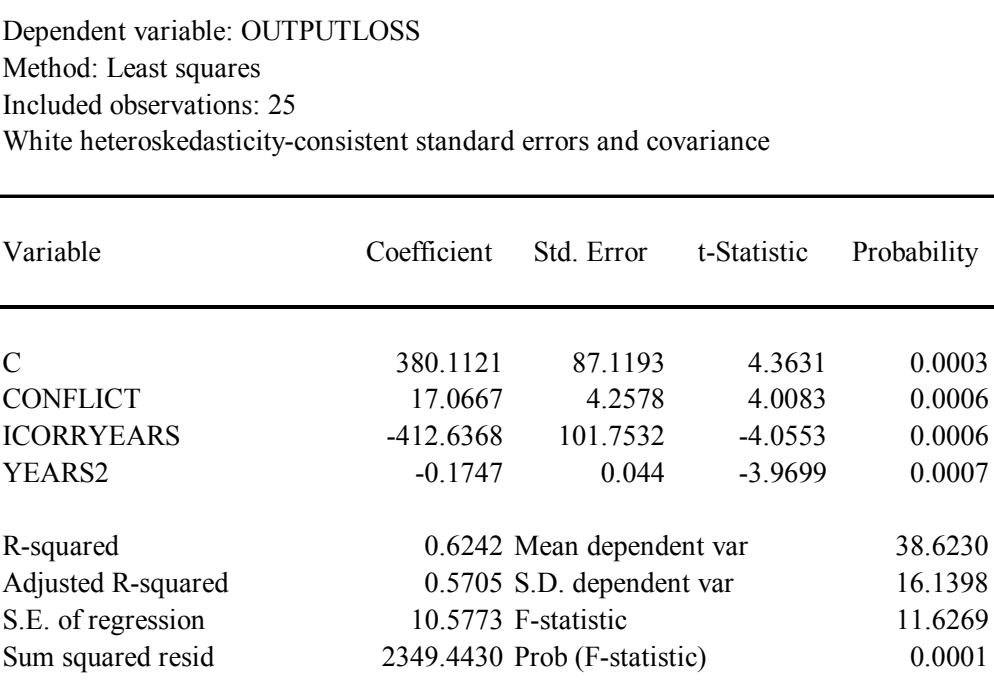

\footnotetext{
${ }^{17}$ The negative sign on the coefficient for the square of the length of the Soviet rule is explained by the inclusion of the same variable (not squared) in the IV equation.
} 


\section{SumMary AND CONCLUSIONS}

In retrospect, the conclusion that the initial stages of transition from central planning to market would entail output losses should have been obvious. Since then, the relative output performance of transition countries has been subject of much debate in the literature. Over time, the emphasis has shifted from explanations of contractions to explanations of relative growth. ${ }^{18}$ Against the backdrop of findings that the patterns of recovery owe much to the modus of the preceding contraction, we consider it unwise to analyze recoveries in isolation from earlier developments. Accordingly, we have suggested a parsimonious model of output contraction, with which we try to assess the extent to which relative differences in the depth of contractions could be explained by concentrating on just two factors: armed conflicts and institutional development. The novel contribution of the paper is to obtain unbiased estimates of the impact of institutions on output by using instrumental variables, an approach that allows us to sidestep the possibility that institutions are not exogenous with respect to output. The particular link we exploit to use the IV approach is between Soviet legacies in place at the outset of the transition and the subsequent institutional development. Thus, the more pervasive the Soviet legacies, or, in other words, the greater the intensity of the communist rule that preceded the transition, the more difficult the subsequent institutional development and the deeper the output contraction. We proxy the extent of Soviet legacies by the length of the communist rule. We also include a nonlinear term for the Soviet rule to account for the possibility of generational or "memory" effects.

The empirical results suggest that more than 60 percent of the variance in relative output performance among transition economies can be attributed to just two factors - conflicts and institutions. To put our findings in perspective, the four groups of countries - Visegrad, Balkans, Baltics, and CIS - have experienced very different contractionary periods, and much has been written on the various country-specific explanatory factors. Without discounting the importance of country-specific factors, we suggest the following two-by-two matrix of common factors as a starting point:

Figure 7. Schematic Classification of Transition Economies

\begin{tabular}{|c|c|c|}
\hline $\begin{array}{r}\text { Soviet } \\
\text { Legacies }\end{array}$ & Limited & Substantial \\
\hline Low & Visegrad countries & Baltics \\
\hline High & Balkans & CIS \\
\hline
\end{tabular}

\footnotetext{
${ }^{18}$ Not surprisingly, this topic has been the leitmotiv of successive EBRD Transition Reports.
} 
Against this backdrop, the exceptionalism of the Chinese transition process can be seen in a new light. While the factors mentioned in Section II are surely quite important, the absence of armed conflict at the time the transition was launched and the relatively short period of central planning (from 1949 until the onset of reforms) should also be noted.

Our framework could be expanded in several directions. The proxy we use is admittedly rather crude and could be refined further. Nevertheless, as we have stressed above, any numerical aggregated measure of the degree to which communism permeated the countries in their pre-transition period is bound to be controversial. Moreover, it is obvious that institutional development depends on many other factors in addition to whatever obstacles that existed at the outset of the transition.

The nature of Soviet legacies needs to be analyzed further. One issue concerns the fact that, despite the enormous costs caused by the Soviet system, both in terms of human lives and economic distortions, the impact of Soviet legacies was not exclusively negative. In this context, one could note that in transition economies (a) measures of educational standards were high relative to other economies at comparable income levels; (b) gender equality was relatively more advanced than in comparator countries, especially in Central Asia; and (c) the existence of various safety nets, however badly designed, made reforms easier. ${ }^{19}$ There is also the possibility of country-specific pre-transition legacies with offsetting effects over time. One example might be the independent labor unions (e.g., Solidarity in Poland), which had tended to limit the effects of the Soviet rule, a positive impact in our framework. Once transition had started, the same labor unions might have had a negative impact on growth, e.g., by limiting real wage flexibility.

In the context of analyzing transition economies, it could be useful to assess the importance for institutional development of signals from the European Union about its willingness to accept these countries as members, and of acquis communitaire as a blueprint for specific steps to be taken. Nonetheless, even in this area, it would be difficult to ensure the exogeneity of measures of institutional development, since it could be argued that the EU was predisposed to give more positive signals to countries that were already growing faster.

\footnotetext{
${ }^{19}$ This point has been stressed in discussing the experience of China by Sen (2000).
} 


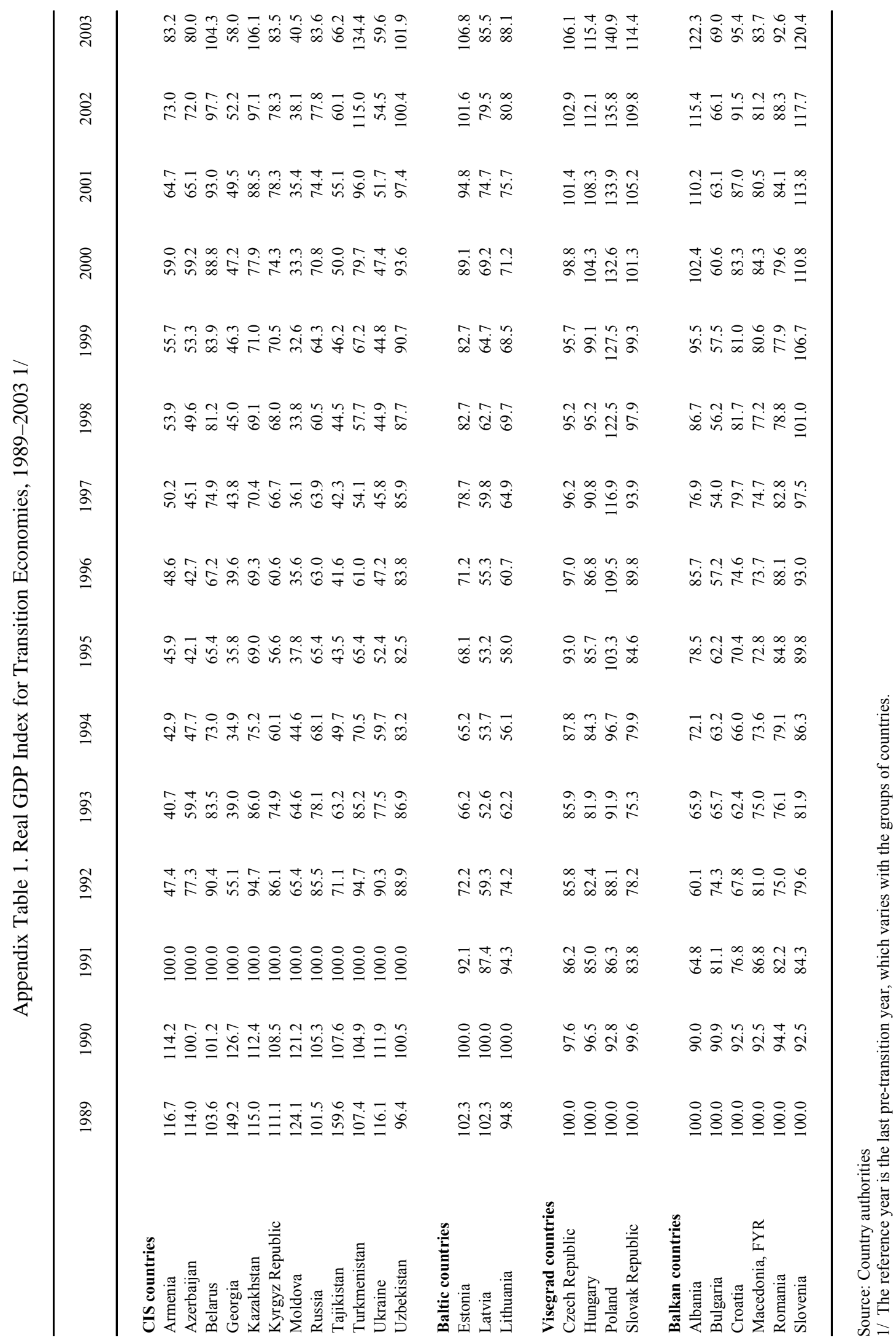


Appendix Table 2. Conflicts During the Early Transition Phase 1/

\begin{tabular}{lccl}
\hline Country & Years of Conflict & $\begin{array}{c}\text { Duration } \\
\text { (in years) }\end{array}$ & Type of Conflict \\
\hline Armenia & $1991-94$ & 4 & war \\
Azerbaijan & $1991-94$ & 4 & war \\
Croatia & $1991-95$ & 5 & war \\
Georgia & $1989-99$ & 11 & violent crisis \\
Moldova & $1991-92$ & 2 & violent crisis \\
Romania & $1989-91$ & 2 & violent crisis \\
Tajikistan & $1990-99$ & 10 & violent crisis \\
\hline
\end{tabular}

Source: SIPRI.

1/ The table excludes the ongoing Chechnya conflict because its relative impact on the Russian economy has likely been rather limited. The war in Bosnia has been excluded because this country is not included in the analysis of this paper, due to lack of sufficiently reliable data. 


\section{References}

Acemoglu, D., Simon Johnson, and James A. Robinson, 2001, "The Colonial Origins of Comparative Development: An Empirical Investigation," American Economic Review, XCI, pp. 1369-1401.

Åslund, Anders, 2001, Building Capitalism: The Transformation of the Former Soviet Bloc (New York: Cambridge University Press).

Berengaut, Julian and others, 1998, The Baltic Countries: From Economic Stabilization to EU Accession, IMF Occasional Paper No. 173 (Washington: International Monetary Fund).

Berengaut, Julian and others, 2002, An Interim Assessment of Ukrainian Output Developments, 2000-01, IMF Working Paper 02/97 (Washington: International Monetary Fund).

Berg, Andrew and others, 1999, The Evolution of Output in Transition Economies: Explaining the Differences, IMF Working Paper 99/73 (Washington: International Monetary Fund).

Bradshaw, Michael, 1999, The Russian Far East: Prospects for the New Millennium (London: Royal Institute for International Affairs).

Carley, Patricia M., 1995, "The Legacy of the Soviet Political System and the Prospects for Developing Civil Society in Asia," in: Vladimir Tismaneanu (ed.), Political Culture and Civil Society in Russia and the New States of Eurasia (New York: Cambridge University), pp. 292-317.

Courtois, S. and others, 1999, The Black Book of Communism: Crimes, Terror, Repression (Cambridge, Massachusetts: Harvard University Press).

De Broeck Mark, and Vincent R. Koen, 2000, "The Great Contractions in Russia, the Baltics and the Other Countries of the Former Soviet Union - A View from the Supply Side," IMF Working Paper 00/32 (Washington: International Monetary Fund).

De Melo, M., 2001, "Circumstances and Choice: the Role of Initial Conditions and Policies in Transition Economies," World Bank Economic Review, Vol. 15, No. 1, pp. 1-31.

Djankov, Simeon and others, 2003, “The New Comparative Economics,” NBER Working Paper 9608 (Cambridge, Massachusetts: National Bureau of Economic Research).

European Bank for Reconstruction and Development (EBRD), Transition Report (London, various issues). 
Elborgh-Woytek, Katrin, 2003, "Of Openness and Distance: Trade Developments in the Commonwealth of Independent States, 1993-2002," IMF Working Paper 03/207 (Washington: International Monetary Fund).

Falcetti, E., M. Reiser, and P. Sanfey, 2002, "Defying the Odds: Initial Conditions, Reforms, and Growth in the First Decade of Transition," Journal of Comparative Economics, Vol. 30, pp. 229-50.

Feshbach, Murray, 1995, Ecological Disaster: Cleaning up the Hidden Legacy of the Soviet Regime (New York: Twentieth Century Fund).

Fischer, S. and R. Sahay, 2000, “The Transition Economies After Ten Years," IMF Working Paper 00/30 (Washington: International Monetary Fund).

Fischer, S., R. Sahay, and C.A. Vegh, 1996, "Stabilization and Growth in Transition Economies: the Early Experience," Journal of Economic Perspectives, Vol. 10, pp. 45-66.

Havrylyshyn, O. and Ron van Rooden, 2003, "Institutions Matter in Transition but so Do Policies," Comparative Economic Studies, Vol. 45, pp. 2-24.

Havrylyshyn, O. et. al. 2000, Growth Experience in Transition Countries, 1990-98, IMF Occasional Paper No. 184 (Washington: International Monetary Fund).

Henley, John S. and George B. Assaf, 1996, "The Challenge for Industrial Development in the Central Asian Republics of the Former Soviet Union," MOCT-MOST, Vol. 6, No. 2, pp. 111-137.

Hill, Fiona, and Clifford G. Gaddy, 2003, The Siberian Curse: How Communist Planners Left Russia out in the Cold (Washington: Brookings Institution).

IMF, 2003, World Economic Outlook (Washington: International Monetary Fund, April).

Kangas, Roger D., 1995, "State Building and Civil Society in Central Asia," in: Vladimir Tismaneanu (Ed.), Political Culture and Civil Society in Russia and the New States of Eurasia, (New York: Cambridge University Press), pp. 271-291.

Kaufmann, Daniel, Art Kraay, and Massimo Mastruzzi, 2003, Governance Matters III: Governance Indicators for 1996-2002, (Washington: World Bank).

Kubicek, Paul, 2002, "Civil Society, Trade Unions and Post-Soviet Democratisation Evidence from Russia and Ukraine," Europe-Asia Studies, Vol. 54, No. 4, pp. 603624. 
Lardy, Nicolas R., 1998, China's Unfinished Economic Revolution (Washington: Brookings Institution).

Lin, Justin Y., Fanc Cai, and Zhou Li, 1996, The China Miracle: Development Strategy and Economic Reform (Hong Kong SAR: Hong Kong Centre for Economic Research).

Makushin, Aleksei, 1993, "From Conversion to Deindustrialization," Problems of Economic Transition, Vol. 35, No. 9 (January), pp. 34-45.

Mnatsakanian, Ruben A., 1992, Environmental Legacy of the Former Soviet Republics (Edinburgh: Centre for Human Ecology).

Peterson, D.J., 1993, Troubled Lands, The Legacy of Soviet Environmental Destruction (Boulder: Westview).

Prasad, Eswar (Ed.), 2004, China's Growth and Integration into the World Economy: Prospects and Challenges, IMF Occasional Paper No. 232 (Washington: International Monetary Fund).

Radulescu, R. and D. Barlow, 2002, "Reform Reversals and Output Growth in Transition," Economics of Transition, Vol. 11, No. 4, pp. 649-67.

Rapaczynski, A., 1996, "The Roles of the State and the Market in Establishing Property Rights," Journal of Economic Perspectives (U.S.), Vol. 10 (Spring), pp. 87-103.

Rutkowski, Michal, 1996, "Labour Market Policies in Transition Economies," MOCTMOST, Vol. 6, pp. 19-38.

Sen, Amartya, 2000, Development as Freedom (New York: Random House).

Tanzi, V. 1996, “Fiscal Developments: An Overview,” MOCT-MOST, No. 3, pp. 1-5.

Tismaneanu, Vladimir (ed.), Political Culture and Civil Society in Russia and the New States of Eurasia (New York: Cambridge University Press).

Wallich, C.I., 1996, "Intergovernmental Finance in Transition Economies," MOCT-MOST, No. 3, pp. 63-86. 